\title{
ACRL Candidates, 1980 Elections
}

The listing for each of the following candidates includes the title, institution, and preferred institutional address.

\section{Vice-President/President-Elect}

Terry Belanger, Assistant Professor, School of Library Service, Columbia University, New York, NY 10027: David C. Weber, Director of Libraries, Stanford University, Cecil H. Green Library, Stanford, CA 94025.

\section{ANThROPOLOGY SECTION}

Vice-Chair/Chair-elect: David R. McDonald, Associate Librarian/Bibliographer for Anthropology, Cubberley Library, Stanford University, Stanford, CA 94305; Suzy M. Slavin, Assistant Head of Reference, McGill University, McLennan Library, Montreal, PQ, Canada.

Member-at-Large (two-year term): Elizabeth Airth, Librarian, Special Services Department, General Libraries, University of Texas at Austin, Austin, TX 78712; Bonnie Nelson, Reference Librarian and Anthropology Subject Specialist, Bobst Library, New York University, New York, NY 10012.

\section{ART SECTION}

Vice-Chair/Chair-elect: John C. Larsen, Associate Professor, School of Library Science, Northern Illinois University, De Kalb, IL 60115; Betty Louise Maurstad, Associate Professor, Division of Library Science, Wayne State University, Detroit, MI 48202.

\section{Asian and African Section}

Vice-Chair/Chair-elect: Mohammed M. Aman, Dean, School of Library Science, University of Wisconsin-Milwaukee, Milwaukee, WI 53201; Donald F. Jay, Chief, Humanities and Social Sciences Research Center, New York Public Library, New York, NY 10018.

Member-at-Large (three-year term): Narindar K. Aggarwal, South and West Asian Librarian, Assistant Head, Asian Library, University of Illinois Library, Urbana, IL 61801; Betty M. Culpepper, Bibliographer/Head of Reference, Moorland-Spingarn Research Center. Howard University, Washington, DC 20059.

\section{Bibliographic Instbuction Section}

Vice-Chair/Chair-elect: Shelley E. Phipps, Orientation Librarian, University of Arizona, Tucson, AZ 85721; Beverly L. Renford, Senior Assistant Librarian, Pennsylvania State University, University Park, PA 16802.

Secretary (one-year term): Patricia W. Silvernail, Head, Access Services, Humanistic and Historical Studies Division, Columbia University Libraries, New York, NY 10027; Arthur P. Young,
Assistant Dean for Public Services, University of Alabama Library, University, AL 35486.

Member-at-Large (two-year term): Olive C. James, Chief, General Reference Division, Green Library, Stanford University, Stanford, CA 94305 ; Mary Reichel, Acting Undergraduate Librarian, State University of New York at Buffalo, Amherst, NY 14260.

\section{College Libraries Section}

Vice-Chair/Chair-elect: Sherrie S. Bergman, College Librarian, Wheaton College, Norton, MA 02766; John Sheridan, Head Librarian, Transylvania University Library, Lexington, KY 40508.

Secretary (two-year term): James E. Ward, Director of the Library, David Lipscomb College, Nashville, TN 37203; Barbara J. Williams, Head Librarian, Miller F. Whittaker Library, Orangeburg, SC 29115.

\section{COMMLNITY and JUNior COLlege LibraRies SECTION}

Vice-Chair/Chair-elect: Paul E. Dumont, Director, Technical Services Center, Dallas County Community College District, Dallas TX 75207; Marcia J. Myers, Chair, Library Program Department, North Campus Library, Miami-Dade Community College, Miami, FL 33167.

Secretary (one-year term): Rosa S. Burnett, Head Librarian, State Technical Institute, Memphis, TN 38134; Harvey Varnet, Assistant Director, Learning Resources Center, Bristol Community College, Fall River, MA 02720

\section{EDLCATION AND BEHAIIORAL SCiENCES SECTION}

Vice-Chair/Chair-elect: Lois J. Lehman, Personnel Librarian, Indiana University Libraries, Bloomington, IN 47401; Ann Randall, Associate University Librarian, Science Library, Brown University, Providence, RI 02912.

\section{Law and Political Science Section}

Vice-Chair/Chair-elect: Artemis C. Kares, Reference Librarian and Assistant Professor, Joyner Library, East Carolina University, Greenville, NC 27834; TBA.

Member-at-Large (one-year term): Mary Lynn Hyde, Head, Technical Services and Documents Librarian, Marvin and Lillian Kratter Law Library, University of San Diego, San Diego, CA 92110; Bettie H. Scott, Assistant Librarian, Law Library, University of California at Davis, Davis, CA 95616.

\section{Rare Books and Manlsciripts Section}

Vice-Chair/Chair-elect: Alexandra Mason, Spencer Librarian, Department of Special Collections, Kenneth Spencer Research Library, Uni- 
versity of Kansas, Lawrence, KS 66045; Daniel H. Traister, Librarian, Rare Book Division, New York Public Library, New York, NY 10018

Member-at-Large (three-year term): Carolyn Harris, Humanities Research Center, University of Texas at Austin, Austin, TX 78712; N. Frederick Nash, Rare Book Librarian, University of Illinois Library, Urbana, IL 61801.

\section{Science and Technology Section}

Vice-Chair/Chair-elect: Charles R. Long, Library, New York Botanical Garden, Bronx, NY 10458; Frank Polach, Agriculture and Botany Resource Librarian, Library of Science and Medicine, Rutgers University, Piscataway, NJ 08854.

Secretary (one-year term): Evelyn P. Fancher, Director, Tennessee State University Library, Nashville, TN 37203; Larry A. Kimble, Life Sciences Librarian, Michener Library, University of Northern Colorado, Greeley, CO 80639.

\section{Slatic and East European Section}

Vice-Chair/Chair-elect: G. Koolemans Beynen, Slavic Bibliographer, Ohio State University Libraries, Columbus, OH 43210; Lubomyr R. Wynar, Professor in the School of Library Science and Director of the Center for the Study of Ethnic Publications in the United States, Kent State University, Kent, OH 44242.

Member-at-Large (one-year term): Kenneth Harris, Bibliographer, Cudahy Library, Loyola University of Chicago, Chicago, IL 60626; Dennis A. Kimmage, Assistant Librarian, Feinberg Library, State University College, Plattsburgh, NY 12901

\section{UNIVERSITY Libraries SECTION}

Vice-Chair/Chair-elect: Joan 1. Gotwals, Associate Director of Libraries, University of Pennsylvania, Philadelphia, PA 19104; Gary L. Menges, Assistant Director for Public Services, General Libraries, University of Texas at Austin, Austin, TX 78712.

\section{Westers European Specialists Section}

Chair: Carolyn F. Bucknall, Assistant Director for Collection Development, General Libraries, University of Texas at Austin, Austin, TX 78712; Kenneth O. Jensen, Director for Collection Development and Acquisitions, Alderman Library, University of Virginia, Charlottesville, VA 22901.

Vice-Chair/Chair-elect: C. Roger Davis, Bibliographer, Smith College Library, Northampton, MA 01063; Mary Jane Parrine, Curator, Romance Languages, Stanford University Libraries, Stanford, CA 94305.

Secretary (one-year term): Eva Kronik, European Studies Librarian, Cornell University, Ithaca, NY 14853; Stephen Lehmann, Humanities Bibliographer, University of Nebraska, Lincoln, NE 68588 .
Member-at-Large (one-year term): Ross Atkinson, Bibliographer, Collection Management Division, Northwestern University Library, Evanston, IL 60201; Elisabeth H. Nebehay, Collection Coordinator, Library, United Nations, New York, NY 10017.

\section{CLR STUDY ON LINKING BIBLIOGRAPHIC UTILITIES}

A study examining the costs, benefits, and methods of linking the existing bibliographic networks has been commissioned by the Council on Library Resources (CLR) as part of its five-year, \$6-million program to promote the creation of a national bibliographic system. The study will be conducted by Batelle-Columbus Laboratories, an Ohio research institute.

The new study will investigate the impact of linking bibliographic utilities on libraries, library users, brokers of bibliographic services, and the utilities themselves. It will focus on the potential costs and benefits of linkage in the areas of cooperative cataloging, interlibrary loan, and online reference searching.

The six-month study will also analyze the alternative methods of linking networks and will develop a model for creating a nationwide network.

Data for the study will be acquired from OCLC, the Research Libraries Information Network (RLIN, the network arm of the Research Libraries Group), the Washington Library Network (WLN), and the Library of Congress.

The study represents a step forward in the Council on Library Resources' Bibliographic Service Development Program. The premise of this program is that national networking should be based on orderly national planning and coordination rather than on ad hoc arrangements. It remains to be seen how central planning will fit in with the competitive situation that now exists in the network field.

\section{Role of Librarians in Curriculum Planning}

Information is needed on the participation of academic librarians in campus curriculum planning and development (e.g., service on curriculum committees, power to accept or veto new course proposals, etc.). Please send any pertinent information to Hannelore $B$. Rader, Coordinator, Education/Psychology, Center of Educational Resources, Eastern Michigan University, Ypsilanti, MI 48197. 